\title{
Iron age burial mounds as refugia for steppe specialist plants and invertebrates - case study from the Zsolca mounds (NE Hungary)
}

\author{
Csaba Albert Tóth ${ }^{1}(\mathbb{D})$, Balázs Deák ${ }^{2}$ (i) , István Nyilas ${ }^{3}$, László Bertalan $^{1}$ (i), \\ Orsolya Valkó ${ }^{4 * *(1)}$, Tibor József Novák ${ }^{5}$ (D)
}

Key words: kurgan, prehistoric mound, loess steppe, biodiversity, cropland matrix, microhabitat, slope, ground-dwelling invertebrates.

Ključne besede: kurgan, predzgodovinske gomile, stepa na lesu, biotska pestrost, kmetisjki matriks, mikrohabitat, pobočje, talni nevretenčarji.
Received: 30. 11. 2018

Revision received: 18. 3. 2018

Accepted: 17. 6. 2019

Coordinating Editor: Stephen Venn

\begin{abstract}
Prehistoric mounds of the Great Hungarian Plain often function as refuges for relic loess steppe vegetation and their associated fauna. The Zsolca mounds are a typical example of kurgans acting as refuges, and even though they are surrounded by agricultural land, they harbour a species rich loess grassland with an area of 0.8 ha. With a detailed field survey of their geomorphology, soil, flora and fauna, we describe the most relevant attributes of the mounds regarding their maintenance as valuable grassland habitats. We recorded 104 vascular plant species, including seven species that are protected in Hungary and two species (Echium russicum and Pulsatilla grandis) listed in the IUCN Red List and the Habitats Directive. The negative effect of the surrounding cropland was detectable in a three-metre wide zone next to the mound edge, where the naturalness of the vegetation was lower, and the frequency of weeds, ruderal species and crop plants was higher than in the central zone. The ancient man-made mounds harboured dry and warm habitats on the southern slope, while the northern slopes had higher biodiversity, due to the balanced water supplies. Both microhabitats had different assemblages of ground-dwelling invertebrates.
\end{abstract}

\section{Izvleček \\ Predzgodovinske gomile v Panonski nižini so pogosto refugiji za reliktno stepsko vegetacijo in z njo povezanim živalstvom. Gomile Zsolca so značilen primer gomil, ki predstavljajo refugije, čeprav so obkrožene s kmetijsko krajino. Na njih najdemo vrstno bogato travišče na lesu s površino 0,8 ha. $Z$ natančno terensko raziskavo njihove geomorfologije, tal, flore in favne smo opisali najpomembnejše dejavnike gomil za ohranjanje pomembnih travniških habitatov. Zabeležili smo 104 višje rastline, vključno s sedmimi vrstami, ki so zavarovane na Madžarskem, in dvema (Echium russicum in Pulsatilla grandis), ki sta na rdečem seznamu IUCN in Habi- tatni direktivi. Negativen vpliv okoliške kmetijske krajine smo zaznali v tri metre širokem pasu ob robu gomile, kjer je bila naravnost vegetacije manjša in frekvenca plevelov, ruderalnih vrst in kulturnih rastlin višja, kot v osrednjem delu. Na južnih pobočjih starodavnih gomil, ki jih je ustvaril človek, najdemo suhe in tople habi- tate, na severni pobočjih pa je pestrost večja zaradi uravnotežene dostopnosti vode. Vrstna sestava talnih nevretenčarjev je bila v obeh mikrohabitatih različna.}

1 University of Debrecen, Department of Physical Geography and Geoinformatics, Egyetem tér 1, 4032 Debrecen, Hungary. E-mail: toth.csaba@science.unideb.hu; bertalan@science.unideb.hu

2 MTA-DE Biodiversity and Ecosystem Services Research Group, Egyetem tér 1, 4032 Debrecen, Hungary. E-mail: debalazs@gmail.com

3 University of Debrecen, Department of Evolutionary Zoology and Human Biology, Egyetem tér 1, 4032 Debrecen, Hungary. E-mail: nyilas.istvan@science.unideb.hu

4 MTA-DE Lendület Seed Ecology Research Group, Egyetem tér 1, 4032 Debrecen, Hungary. E-mail: valkoorsi@gmail.com

5 University of Debrecen, Department of Landscape Protection and Environmental Geography, Egyetem tér 1, 4032 Debrecen, Hungary. E-mail: novak.tibor@science. unideb.hu

* Corresponding author 


\section{Introduction}

Almost half a million ancient burial mounds, with heights of 3-12 meters, are located in the Eurasian steppe and forest steppe zones (Deák et al. 2016a, 2019). These mounds were predominantly built for burial purposes from the Late Neolithic to the Early Middle Ages (4500 $\mathrm{BC}-900 \mathrm{AD})$. The westernmost occurrences of such mounds are in the plain areas of the Carpathian Basin, especially on the flood-free terraces and levees of the Great Hungarian Plain. The mounds have always been the focus of archaeological interest (Selmeczi 1971, Szilágyi et al. 2019). In recent decades, the nature conservation value of the mounds has also been recognised in Hungary (Tóth 2006, Deák et al. 2016b). They are all protected (53/1996. Law on Nature Conservation) and included as representative features of the Hungarian landscape in the European Landscape Convention (Jones 2007). The law prescribed a cadastral survey of the mounds, which was implemented in 2002. As a result, 1679 mounds were registered in Hungary (Tóth 2006, Tóth \& Tóth 2011). Various geo-archaeological, soil and paleo-ecological research projects were conducted during the national cadastral work, and their results contributed to the paleoenvironmental reconstruction of the mounds and also provided information on the construction of the mounds (Molnár et al. 2004, Molnár \& Svingor 2011).

Among the arid lowland grasslands, the Pannonic loess steppic grasslands (Festucion rupicolae Soó 1940) are of crucial conservational importance in the European Union, since the extent of these habitats has decreased dramatically over recent centuries (Biró et al. 2018, Zólyomi \& Fekete 1994). Due to the large-scale agricultural intensification, the last remnants of species-rich loess grasslands remain in just a few nature reserves, and in sites that were not used for crop production, such as roadside verges (Csathó 2011), old cemeteries (Molnár V. et al. 2017, 2018) and ancient burial mounds (Bede et al. 2015, Deák et al. 2016b, Dembicz et al. 2016). The mounds contain habitats with special ecological conditions due to their shape, small extent and isolatedness (Deák et al. 2016a, b, 2017). In general, there is no grazing by large herbivores on the mounds (Deák et al. 2018), but they serve as suitable habitat for a few ground-dwelling species (fox, badger), which cause strong pedoturbation, due to the excavation of burrows (Godó et al. 2018). The various aspects of the mound slopes provide micro-habitats with various environmental conditions (Deák et al. 2017). On isolated mounds, the dynamics of plant species are determined by the principles of island biogeography (Diamond \& May 1976), because these mounds are surrounded by cultivated lands, and the closest similar habitats are located at a distance of several kilometres (Deák et al. 2018).

The aim of our study was a complex botanical, zoological and landscape ecological investigation of the Zsolca Mounds in Northeast Hungary (Figure 1). The two mounds were constructed from tens of thousands of cubic metres of loess material, excavated from the bedrock and chernozem soil, several centuries ago. In this study our main aims were to:

- determine the geomorphological parameters of the mounds

- determine the topsoil features (soil temperature, soil moisture, $\mathrm{pH}$, carbon and organic matter content)

- study the plant species composition of the loess grassland and to reveal the effect of the surrounding cropland on the vegetation of the mounds

- investigate the ground-dwelling arthropod assemblages of the slopes of various aspects.

The fieldwork for this study was performed between 2006 and 2009.

\section{Materials and methods}

\section{Study site}

The Zsolca Mounds are twin mounds, separated by a distance of 30 meters. The mounds are located on the floodfree terrace of the Sajó river (N48 07'02"; E20 $52^{\prime} 54^{\prime \prime}$ ), where the Great Hungarian Plain joins the North-Hungarian Mid-Mountains (Figure 1). In our earlier study, we estimated the date of the construction of the mounds, on the basis of radiocarbon dating of the soils and sediments filling the ditches. According to our findings, the mounds were constructed by Scythians during the 5-6 $6^{\text {th }}$ century BC. (Tóth et al. 2014).

\section{Geodetic measurements}

We performed detailed geodetic measurements with an infra total station (Geodolite), in order to describe the geomorphological characteristics of the mounds and their environment. We created a digital elevation model of the sample area on the basis of the results of the geodetic measurements, using the Surfer 11 software. We derived the morphometric parameters of the mounds from the digital elevation model.

\section{Soil analysis}

We designated in total 28 quadrats for vegetation and soil sampling in 2006. Three soil samples were collected from the top $6 \mathrm{~cm}$ of soil from every investigated $1 \mathrm{~m} \times 1 \mathrm{~m}$ 

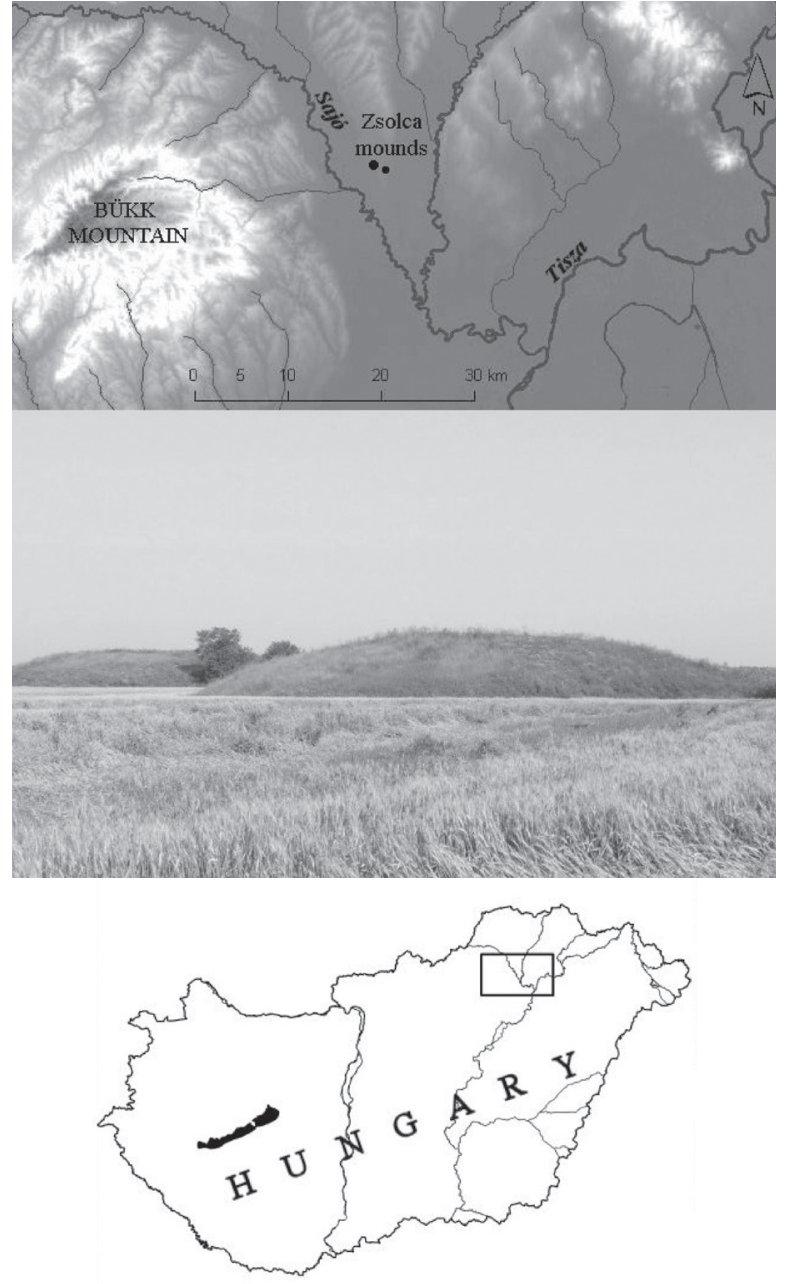

Figure 1: The geographical location and the summer appearance of the Zsolca mounds (Photo: Tóth, C. A.).

Slika 1: Geografska lokacija in poletni izgled gomile Zsolca (Foto: Tóth, C. A.)

quadrat, using a sampler with a volume of $100 \mathrm{~cm}^{3}$. The organic matter and carbon content were analysed using the wet oxidation method (Ponomerova \& Plotnikova 1980). The $\mathrm{pH}$ values of the soil samples were measured using a standard glass electrode in 1:2.5 suspensions (soil : $\mathrm{H}_{2} \mathrm{O}$ and soil : $10 \% \mathrm{KCl}$ solution). The field moisture content was analysed by measuring weight loss during exsiccation until constant weight at $105^{\circ} \mathrm{C}$. The field temperature of each soil sample was measured using a digital thermometer.

\section{Vegetation sampling}

We recorded the number of plant species and their percentage cover on the mounds during each season (spring, summer and autumn) of the vegetation period. We designated permanent quadrats on the eastern mound to evaluate the effect of the surrounding croplands on the vegetation of the loess grassland on the mounds. The quadrats were installed on the slopes in the four cardinal directions (north, east, south and west) from the edge to the centre of the mound, and also in the central area of the mound. In total, six quadrats were designated on each slope, and four additional quadrats were designated on the top of the mounds (i.e. flat area without distinct aspect). The percentage cover of the vascular plant species was recorded in each quadrat in May, June and the end of August.

The plant nomenclature follows Simon (1992). We evaluated the naturalness of the vegetation using the naturalness values of Borhidi (1993). The system of Borhidi (1993) is an adaptation of the Ellenberg indicator values (Ellenberg et al. 1992) to Hungarian conditions, additionally ranked by naturalness and corrected by the general frequency of the species within the Hungarian flora (Borhidi 1993). The naturalness values of the plant species range from -3 to +10 , with +10 indicating the highest level of naturalness. We calculated the average naturalness values of the species present in each quadrat by grouping the four quadrats at a given distance from the cropland together.

\section{Zoological sampling}

We installed pitfall traps for collecting ground-dwelling arthropods. The pitfall traps consisted of a plastic container of half litre in size, set in the ground with its rim at the soil surface level. We used ethylene glycol in the traps to kill and preserve the trapped animals. We installed 10 traps on the northern and southern slopes of both mounds (altogether 40 traps). The duration of the sampling period was two weeks. Of the factors potentially affecting the species composition of arthropod assemblages, we measured soil temperature, water content and $\mathrm{pH}$, and air temperature at five locations in each selected habitat.

\section{Results}

\section{Geomorphological investigations}

The total area of the mounds covers 0.8 hectares. Due to the steep slopes of the 5.8-6 m high mounds, they have not been cultivated. Originally there were $2.5-3 \mathrm{~m}$ deep ditches around the mounds. In spite of the intense cultivation, and even though the depth of the ditches has decreased, they are still clearly discernible at the bottom of the mounds (Figure 2). The bulk of the mounds is made up of unstratified, heterogeneous and tawny-coloured loess-like sediment (Tóth et al. 2014). 


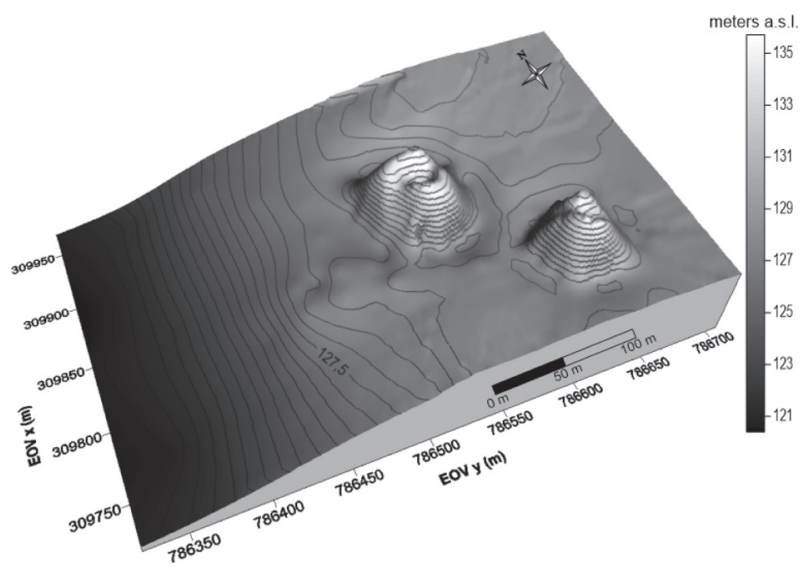

Figure 2: Digital elevation model of the Zsolca mounds. Slika 2: Digitalni model višin gomil Zsolca.

The mounds were classified as damaged from a geomorphological perspective, due to the presence of large craterlike depressions at the top of both mounds. It is uncertain how these depressions were created, and for what purpose. It is likely that over previous centuries treasure hunters have excavated the central area of the mounds many centuries ago. The most important morphometric parameters of the two mounds are summarized in Table 1.

Table 1: Morphometric parameters of the Zsolca mounds. Tabela 1: Morfometrični parametri gomil Zsolca.

\begin{tabular}{lcc} 
& Mound West & Mound East \\
diameter & $80 \mathrm{~m}$ & $60 \mathrm{~m}$ \\
perimeter of the base circle & $251 \mathrm{~m}$ & $188 \mathrm{~m}$ \\
base area & $5024 \mathrm{~m}^{2}$ & $2826 \mathrm{~m}^{2}$ \\
height (relative) & $6 \mathrm{~m}$ & $5,8 \mathrm{~m}$ \\
height (a.s.l.) & $132.6 \mathrm{~m}$ & $132.4 \mathrm{~m}$ \\
slope & $10-17^{\circ}$ & $10-15^{\circ}$ \\
volume & $10610 \mathrm{~m}^{3}$ & $6802 \mathrm{~m}^{3}$ \\
\hline
\end{tabular}

\section{Soil parameters}

A thick chernozem-type soil layer formed on the surface of the mound-body, comprising loess-like sediment that has accumulated over almost 2,500 years (Tóth et al. 2014). The average organic matter content of the soil samples, collected from points on the edge at the four cardinal directions and from the central area of the mounds, was $5.7 \pm 1.9 \%$ (Figure 3 ). We measured a high value $(10 \%)$ at the centre of the eastern mound, where a greater amount of organic matter had accumulated at the bottom of the artificial depression. The $\mathrm{CaCO}_{3}$ content of the samples was $3.9 \pm 2.0 \%$ (Figure 3 ). The variation in the inorganic carbon content of the topsoil could be the result of the different degrees of erosion on the mound sides, due to their higher slope inclinations. The loess-like material, with its high carbon content, is located closer to the surface on the steeper sides of the mounds. The changes in the carbon content were correlated with the $\mathrm{pH}$ values of the soil (Figure 3), as the average values in the aqueous soil-extract were $7.3 \pm 0.3$, while in the potassium chloride-based extract they were $7.0 \pm 0.3$.

We found that a considerable microclimatic difference developed between the steep northern and southern sides (Figure 3). On a late spring day at around noon with an air temperature of $20^{\circ} \mathrm{C}$, the soil temperature varied between 14.5 and $18.9^{\circ} \mathrm{C}$ at the southern mound-edge, and 10.9 to $13.8^{\circ} \mathrm{C}$ at the northern edge. We measured the maximum soil temperature $\left(21.4^{\circ} \mathrm{C}\right)$ at the top of the mound, on the edge of its southern aspect. The soil moisture was lower (4-9 vol. \%) on the southern side of the mound than it was on the northern side, with its more balanced water supply (10-13 vol. \%, Figure 3).

\section{Vegetation composition}

We recorded a total of 104 plant species on the combined area of the two mounds. We found loess grasslands (SalvioFestucetum rupicolae Zólyomi ex Soó 1964) on both of the mounds. Festuca rupicola was the main grassland-forming species, and in a few patches Agropyron repens, and some dicotyledonous species, such as Thalictrum minus, Cytisus albus, Phlomis tuberosa, and Inula hirta, had the highest coverage.

On the slopes with a southern aspect, we found patches dominated by Stipa capillata. At these locations, Koeleria cristata and Carex stenophylla were the co-dominant species. Other typical grass species were Botriochloa ischaemum and Bromus erectus. Species richness was greatest at the tops of the mounds and on the northern and the north-eastern slopes. Among the typical species of loess grasslands, Galium verum, Veronica spicata, Verbascum phoeniceum, Salvia nemorosa, S. pratensis, S. austriaca, Thymus glabrescens, Filipendula vulgaris, Muscari comosum, Pulsatilla grandis and Aster amellus were abundant. We found several species with a high conservation value, such as Echium russicum, Linum flavum, Centaurea triumfettii and Dictamnus albus, though with small cover.

The averaged naturalness values showed a considerable difference when we grouped the first three quadrats of the 6 meter long transects into an "edge" group and the inner three quadrats into a "central" group (Figure 4). In Figure 4, we indicate the average naturalness values along a gradient from the edge to the central areas, calculated for the four quadrats located at equal distances from the cropland. Based on the naturalness values, it is clear that quadrats located within a distance of 3 meters from the 


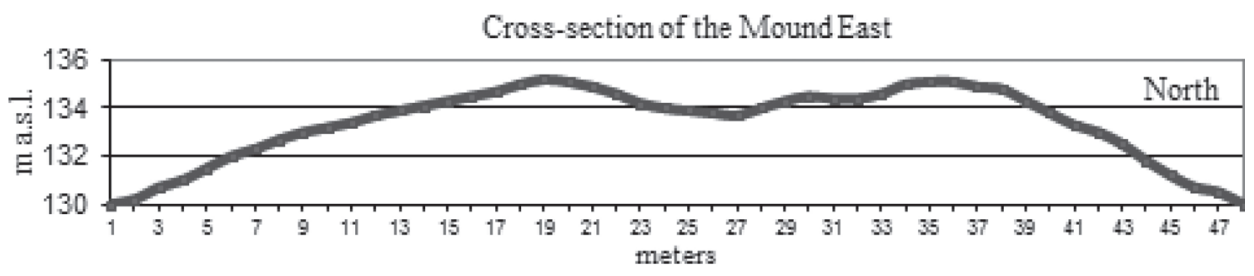

Soil temperature

$\left(20^{\circ} \mathrm{C}\right.$ air temperature, a clear day at noon and $6 \mathrm{~cm}$ deep)

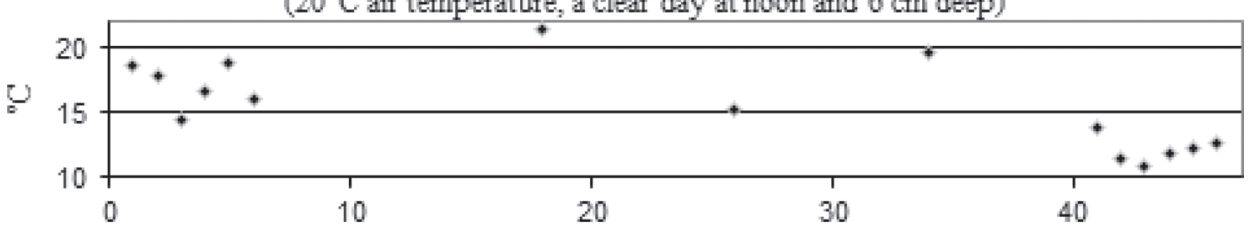

Soil moisture (wol.\%)
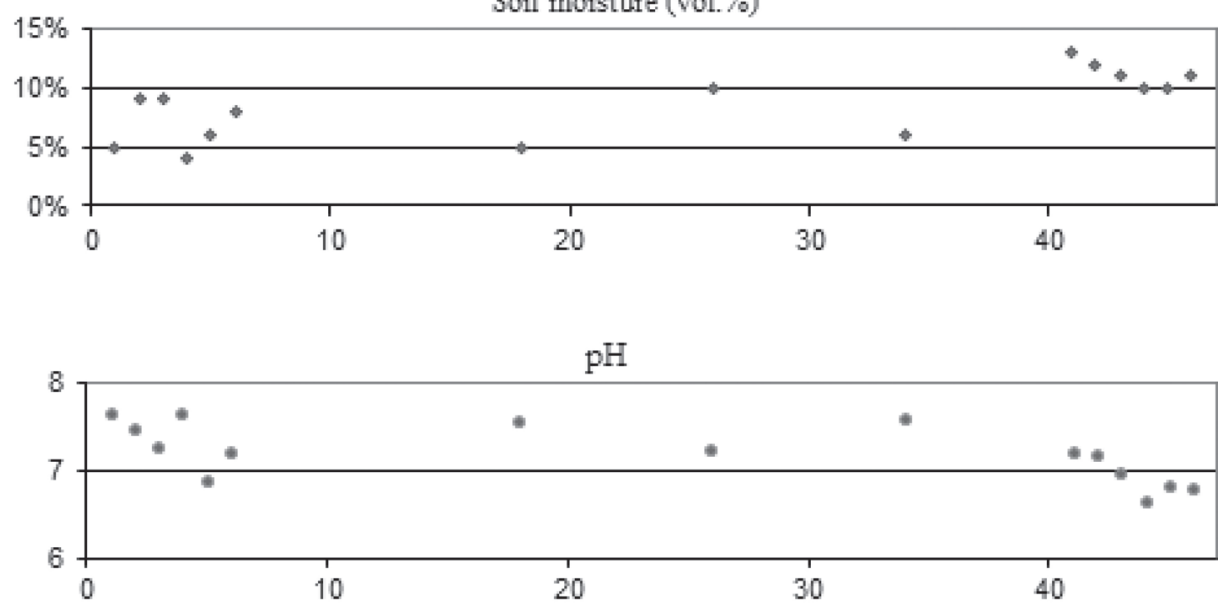

$\mathrm{CaCO}_{3}(\%)$

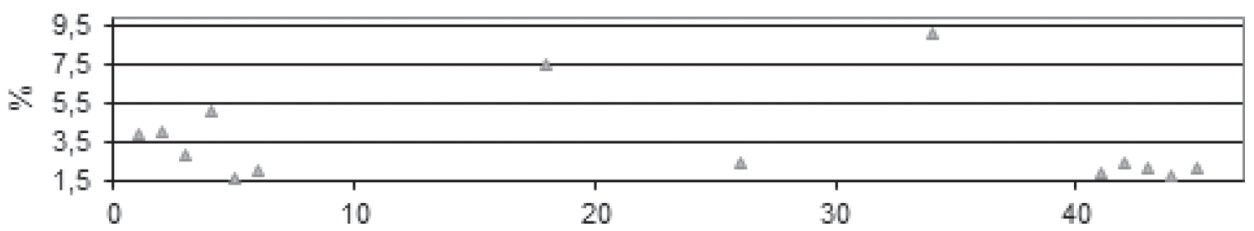

Organic matter content (\%)

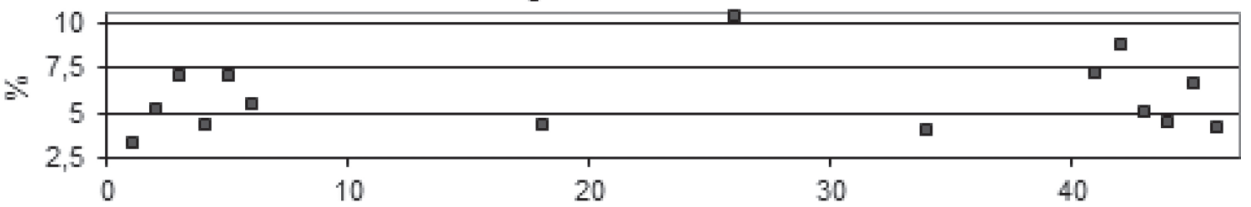

Figure 3: Cross-section of the eastern Zsolca-mound (first panel) and the results of topsoil analysis. The location of the dots refer to the location of sampling plots (south slope, top, north slope).

Slika 3: Prečni prerez čez vzhodno gomilo Zsolca (prva slika) in rezultati analize vrhnjega dela tal. Položaj točk odgovarja položaju vzorčnih točk (južno pobočje, vrh, severno pobočje). 


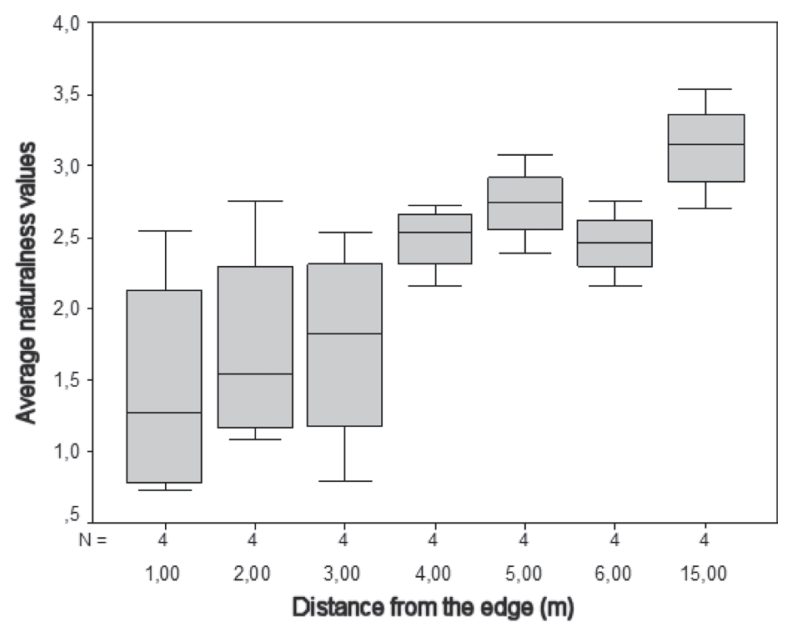

Figure 4: Average naturalness values per quadrat along a gradient from the edge. Boxes indicate $25-75$ percentiles, lines are medians, and whiskers are standard deviations. Average naturalness values refer to the cover-weighted naturalness values of Borhidi (Borhidi 1993). The system of Borhidi (1993) is an adaptation of the Ellenberg indicator values (Ellenberg et al. 1992) to Hungarian conditions, additionally ranked by naturalness and corrected by the general frequency of the species within the Hungarian flora. The naturalness values of the plant species range from -3 to +10 , with +10 indicating the highest level of naturalness. We calculated the averaged naturalness values of the species present in each quadrat by grouping the four quadrats at a given distance from the cropland together.

Slika 4: Povprečne vrednosti naravnosti za vzorčni kvadrat od roba vzdolž gradienta. Škatle prikazujejo 25-75 percentilov, črte so mediane, brki pa standardni odkloni. Povprečna naravnost se nanaša na vrednosti naravnosti po Borhidiju (Borhidi 1993), ki so utežene s pokrovnimi vrednostmi. Sistem po Borhidiju (1993) je prilagoditev Ellenbergovih indikatorskih vrednosti (Ellenberg et al. 1992) razmeram na Madžarskem, dodatno vrednoten po naravnosti in umerjen s splošno frekvenco vrst v flori Madžarske. Vrednosti naravnosti rastlinskih vrst imajo razpon od -3 do +10 , ki nakazuje najvišjo stopnjo naravnosti. Za vrste v vsaki vzorčni ploskvi smo izračunali povprečno vrednost naravnosti z združitvijo štirih ploskev na določeni razdalji od okoliških obdelanih polj.

cropland have considerably lower naturalness than those located further from the cropland. Naturalness values were highest in the central areas of the mounds, in the quadrats located $15 \mathrm{~m}$ far from the edges.

In Table 2, we give the five most frequent species in the 'edge' and 'central' quadrats based on the presence-absence data and list those species that proved to be differential for the two zones. We found ruderal species and arable weeds amongst the species that occur only at the edge, and commercial crops and arid grassland species also appeared. Outside the quadrats in the edge zone, we recorded a few adventive weed species, such as Abutilon theophrasti, Ambrosia artemisiifolia, Xanthium strumarium and Conyza canadensis. The majority of the species that occurred only in the central zone were loess grassland specialist species, including Aster amellus and Pulsatilla grandis, which are protected in Hungary.
Table 2: Plant species occurring exclusively at the edge (left) and central (right) zones, listed by their frequency $\left(\mathrm{F}_{\mathrm{e}}=\right.$ frequency in edge, $\mathrm{F}_{\mathrm{c}}=$ frequency in central).

Tabela 2: Rastlinske vrste, ki se pojavljajo izključno na robu (levo) in v osrednjem delu (desno), razvrščene po frekvenci $\left(\mathrm{F}_{\mathrm{e}}=\right.$ frekvenca na robu, $\mathrm{F}_{\mathrm{c}}=$ frekvenca na sredini).

\begin{tabular}{|c|c|c|c|}
\hline Edge zone & $\begin{array}{c}F_{e} \\
(N=12)\end{array}$ & Central area & $\begin{array}{c}F_{c} \\
(N=16)\end{array}$ \\
\hline Arctium lappa & 0.25 & Inula hirta & 0.50 \\
\hline Artemisia vulgaris & 0.25 & Muscari comosum & 0.25 \\
\hline Atriplex patula & 0.25 & Aster amellus & 0.25 \\
\hline Fragaria vesca & 0.25 & Anthericum ramosum & 0.25 \\
\hline Rumex obtusifolius & 0.25 & Salvia pratensis & 0.19 \\
\hline Matricaria inodora & 0.17 & Rumex acetosa & 0.19 \\
\hline Viola arvensis & 0.17 & Veronica austriaca & 0.13 \\
\hline Knautia arvensis & 0.08 & Verbascum phoeniceum & 0.13 \\
\hline Medicago falcata & 0.08 & Dianthus pontederae & 0.13 \\
\hline Medicago sativa (cult.) & 0.08 & Betonica officinalis & 0.13 \\
\hline Sonchus arvense & 0.08 & Achillea nobilis & 0.13 \\
\hline Taraxacum officinale & 0.08 & Thymus glabrescens & 0.06 \\
\hline \multirow[t]{10}{*}{ Triticum aestivum (cult.) } & 0.08 & Salvia austriaca & 0.06 \\
\hline & & Rosa gallica & 0.06 \\
\hline & & Ranunculus acris & 0.06 \\
\hline & & Pulsatilla grandis & 0.06 \\
\hline & & Pimpinella saxifraga & 0.06 \\
\hline & & Lamium amplexicaule & 0.06 \\
\hline & & Hypericum perforatum & 0.06 \\
\hline & & Carex caryophyllea & 0.06 \\
\hline & & Botriochloa ischaemum & 0.06 \\
\hline & & Asperula cynanchica & 0.06 \\
\hline
\end{tabular}

\section{Animal assemblages}

In total, 36 invertebrate species were caught in the pitfall traps (Appendix 1 and Appendix 2).

Two steppe-specialist Mollusc species, Chondrula tridens and Helicella obvia, which were mainly associated with warm, dry slopes with a southern aspect, were recorded. In addition, specimens of three Heteroptera species, Cydnus aterrimus and Coptosoma scutellatum, which have a broad ecological tolerance, and Sciocoris cursitans, which mainly prefers dry and warm habitats, were recorded. A total of 31 species of beetle (Coleoptera) were recorded. The nine species of the Carabidae family included the nationally protected Carabus cancellatus and Carabus violaceus, which occurred on the northern slopes. Similarly, two species of the Silphidae family (Silpha obscura and Nicrophorus fossor) preferred the dense vegetation of the northern slopes. The flightless Blaps lethifera (Tenebri- 
onidae), Onthophagus ovatus (Scarabaeidae), Chrysomela limbata and Cryptocephalus bipunctatus (Chrysomelidae), as well as the nationally protected Dorcus parallelipipedus (Lucanidae), were recorded from the northern slopes of the mounds. The species preferring the grasslands of the southern slopes were Harpalus griseus (Carabidae), Hippodamia variegata (Coccinellidae), Opatrum sabulosum (Tenebrionidae), Rhizotrogus aestivus (Scarabaeidae) and Baris lepidii (Curculionidae). There were three Coleoptera species Trechus quadristriatus, Panagaeus bipustulatus (Carabidae) and Dorcadion scopolii (Cerambycidae), which were mostly recorded from the northern slopes.

\section{Discussion}

\section{The mounds as refuges}

The Zsolca mounds, with 5.8-6 m relative heights and diameters of $60-80 \mathrm{~m}$, had not been involved into cultivation, probably due to their steep slopes $\left(10-17^{\circ}\right.$; see Deák et al. 2016a), in contrast to nearly half (47\%) of the lowland mounds that had been completely cultivated (Tóth \& Tóth 2011). Even though the investigated mounds are much smaller than the 15-20 meters high Scythian kurgans of the Ukrainian and South-Russian steppes (Kitov 1993, Mozolevsky \& Polin 2005), in Hungary they are classified as considerably large (Tóth 2006). Despite the fact that the tops of the mounds have been truncated, they are still highly valuable from the landscape aesthetical and socio-cultural perspective (Tóth 2006, Tóth \& Tóth 2011).

The Zsolca mounds were built by the Scythians, approximately 2000 years later than the mounds of the Yamnaya culture, which are more frequent in the Great Hungarian Plain (Tóth et al. 2014). Unlike the mounds built by the Yamnayas, where only the humus-rich topsoil was used for their construction, Schythian mounds were constructed using topsoil and loess rock. As a result, deeper pits were formed around the mounds, contrary to the majority of the kurgans in the Great Hungarian Plain (Barczi et al. 2006). The topsoil analysis of the Zsolca mounds revealed a fertile chernozem type soil, with high organic matter content. Due to the loess material, the $\mathrm{pH}$ values and carbon content of the topsoil on the Zsolca mounds are higher compared to the mounds built by the Yamnayas (Barczi et al. 2006).

Despite their small area, the Zsolca mounds act as refuges for grassland species in the intensively used agricultural landscape. The steep slopes of the mounds have protected the habitats from the negative influence of agriculture (i.e. ploughing) and by providing a high level of microhabitat heterogeneity they probably support the coexistence of multiple plant and animal species with different habitat requirements. High habitat and plant species diversity, driven by the high level of environmental heterogeneity, was also observed on other Hungarian (Joó 2003), Ukrainian (Sudnik-Wójcikowksa et al. 2011), Russian (Lisetskii et al. 2014, 2016) and Kazakh (Deák et al. 2017) mounds as well. In particular, significant differences were observed in the soil temperature and the moisture of the northern and southern slopes. The diversity of the plant species increased with increasing heterogeneity of the habitats, as was also described in the case of the Ecse mound and the Csípő mound (Bede et al. 2015, Barczi et al 2006, Joó 2003).

In total we recorded 104 vascular plant and 36 invertebrate species. In terms of the number of plant species, the Zsolca mounds have one of the greatest species diversities of the Hungarian mounds, however nearly the same species number was described in the case of the Csípő mound (Joó 2003), Ecse mound (Bede et al. 2015) and the Mondró mound (Deák et al. 2015). Regarding the number of animal species, a comparison cannot be made owing to the lack of zoological information of the mounds (Deák et al. 2016a) and the fact that only few animal taxa (e.g. Orthoptera species) had been studied previously (Gallé et al. 1992, Krausz \& Pápai 2004).

We found in total seven plant species that are protected in Hungary, namely Aster amellus, Centaurea triumfettii, Dictamnus albus, Echium russicum, Linum flavum, Phlomis tuberosa and Pulsatilla grandis, most of which have not been recorded on other Hungarian mounds (Joó 2003, Bede et al. 2015, Deák et al. 2015). Echium russicum and Pulsatilla grandis are listed in the Red List of IUCN (category: Least Concern, LC) and also in the Annex of the EU Habitats Directive. We recorded several animal species that are protected in Hungary, such as Carabus cancellatus, C. violaceus, Dorcus parallelipipedus.

\section{Effect of the surrounding cropland on the vegetation composition}

Our results suggest that the surrounding cropland has a considerable effect on the edge zone of the mound. We observed the presence of ruderal species, arable weeds and several crop plants on the edge zone of the mound. We also detected lower naturalness values in the vegetation of the edge zone than in the central parts of the mounds. The effect of the surrounding matrix was the highest in an approximately three-meter wide zone adjacent to the cropland. This suggests that for the long-term conservation of the ecological values of the mounds, the estab- 
lishment of an at least 50-metre-wide and uncultivated buffer-zone at the edge of the mounds is essential (see Valkó et al. 2018). Hay transfer from the central parts of the kurgans (which are not infested by weedy species) would be the most proper measure to establish such a buffer zone. On the one hand, hay that has originated from the kurgan itself contains only the propagules of target species, and on the other hand the hay cover might prevent weed encroachment.

\section{Microhabitats of the southern and northern slopes}

We detected marked differences between the temperatures and the soil moisture at different slope aspects. According to our spring measurements, the average temperature difference between the northern and southern sides of the mounds was $4.35^{\circ} \mathrm{C}$, while our summer measurements indicated a difference of $7.96^{\circ} \mathrm{C}$. We recorded the highest species richness of ground-dwelling invertebrates on the northern slopes of the mounds (Appendix 2). The mounds have quite arid, sunny and warm habitats on the southern slopes, while the northern slopes have dense vegetation and higher plant and animal species richness due to the moist habitat conditions (less evaporation) (Sudnik-Wójcikowksa et al. 2011, Lisetskii et al. 2014, 2016). Most of the Heteroptera and Coleoptera species, which are mainly scavenger, predator, seed predator and decaying plant feeding insects, prefer the cooler northern slopes with dense vegetation. In addition, arthropods specific to the woodlands or shrublands, also prefer the northern slopes as temporal habitats, e.g. Dorcus parallelipipedus (Lucanidae), Cryptocephalus bipunctatus (Chrysomelidae) and Pterostichus niger (Carabidae). On the dry, warm, southern slopes, xerophilous grounddwelling invertebrate assemblages with thermophilic and drought-tolerant Carabidae, Coccinellidae, Tenebrionidae, Scarabaeidae, Curculionidae species, are typical.

\section{Conclusions}

In spite of their former truncation and the intensive agricultural cultivation of their surroundings, they still harbour valuable loess grasslands. We recorded 104 plant and 47 animal species, including two red-listed plant species (Echium russicum, Pulsatilla grandis). Nonetheless, the mounds are populated by several loess grassland specialist plant and animal species, which are protected in Hungary and have become rare in the intensively used agricultural landscapes. We found that the effect of the neighbouring cropland is detectable on the vegetation of an approximately 3 meter-wide zone next to the edge of the mound with a vegetation dominated mostly by ruderal and arable weed species. We demonstrated that the steep slopes with different aspects provide various microhabitats characterised by contrasting plant and animal communities. We found the highest number of ground-dwelling invertebrate species on the cooler and more humid northern slopes compared to the warmer and drier southern slopes. The mounds retain representative vegetation and animal species of loess steppe habitats but without specific measures to avoid their degradation through invasion by weeds, their assemblages are likely to decline and eventually be lost, with a major impact on regional biodiversity.

\section{Acknowledgements}

Authors are grateful for Stephen Venn, Co-ordinating Editor of the paper for his valuable suggestions and linguistic edition of the manuscript. The authors were supported by the NKFI KH 130338 project (CAT, BD, TN), the NKFI FK $124404(\mathrm{OV})$, and the NKFIH KH 126476 (OV). The authors were supported by the Bolyai János Research Scholarship of the Hungarian Academy of Sciences (BD, OV) and by the ÚNKP-18-4-DE-9 and ÚNKP-18-4-DE-12 New National Excellence Programme of the Ministry of Human Capacities.

The research was supported by the European Union and the State of Hungary, co-financed by the European Regional Development Fund (EFOP-3.6.1-16-201600022 "Debrecen Venture Catapult program").

\footnotetext{
Csaba Albert Tóth (D), https://orcid.org/0000-0002-0934-135X

Balázs Deák (D), https://orcid.org/0000-0001-6938-1997

László Bertalan (D), https://orcid.org/0000-0002-5963-2710

Orsolya Valkó (D), https://orcid.org/0000-0001-7919-6293

Tibor József Novák (D), https://orcid.org/0000-0002-5514-9035
} 


\section{References}

Barczi, A., Joó, K., Pető, Á. \& Bucsi, T. 2006: Survey of the Buried Paleosol under the Lyukas Mound in Hungary. Eurasian Soil Science 39 (1): $133-140$

Bede, Á., Salisbury, R. B., Csathó, A. I., Czukor, P., Páll, D. G., Szilágyi, G. \& Sümegi, P. 2015: Report of the complex geoarcheological survey at the Ecse-halom kurgan in Hortobágy, Hungary. Central European Geology 58(3): 268-289. doi: https://doi. org/10.1556/24.58.2015.3.5

Biró, M., Bölöni, J. \& Molnár, Zs. 2018: Use of long-term data to evaluate loss and endangerment status of Natura 2000 habitats and effects of protected areas. Conservation Biology 3: 660-671. doi: https://doi.org/10.1111/cobi.13038

Borhidi, A. 1993: A magyar flóra szociális magatartástípusai, természetességi és relatív ökológiai értékszámai [Social behavior-types, naturalness and relative ecological values of the Hungarian flora]. JPTE Növénytani Tanszék, Pécs, p. 93. (in Hungarian)

Csathó, A. I. 2011: Az elsődleges és másodlagos mezsgyék növényzetének összehasonlító vizsgálata a battonyai Gránic- és Csárda-dűlő példáján [Differences between the vegetation of primary and secondary verges - examples of the Gránic- and Csárda-dűlö, Battonya]. Tájökológiai Lapok 9 (2): 345-356. (in Hungarian)

Deák, B., Török, P., Tóthmérész, B. \& Valkó, O. 2015: A hencidai Mondró-halom, a löszgyep-vegetáció őrzője [The Mondró-mound of Hencida, guardian of the loess-grassland vegetation]. Kitaibelia 20 (1): 143-149. (in Hungarian)

Deák, B, Tóthmérész, B., Valkó, O., Sudnik-Wójcikowska, B., Moysiyenko, I.I., Bragina, T.M., Apostolova, I., Dembicz, I., Bykov, N.I. \& Török, P. 2016a: Cultural monuments and nature conservation: a review of the role of kurgans in the conservation and restoration of steppe vegetation. Biodiversity and Conservation 25: (293) 1-18. doi: https://doi.org/10.1007/s10531-016-1081-2

Deák, B., Valkó, O., Török, P. \& Tóthmérész, B. 2016b: Factors threatening grassland specialist plants - A multi-proxy study on the vegetation of isolated grasslands. Biological Conservation 204: 255-262. doi: https://doi.org/10.1016/j.biocon.2016.10.023

Deák, B., Tölgyesi, Cs., Kelemen, A., Bátori, Z., Gallé, R., Bragina, T.M., Abil, Y.A. \& Valkó, O. 2017: The effects of micro-habitats and grazing intensity on the vegetation of burial mounds in the Kazakh steppes. Plant Ecology and Diversity 10: 509-520. doi: https://doi.org $/ 10.1080 / 17550874.2018 .1430871$

Deák, B., Valkó, O., Török, P., Kelemen, A., Bede, Á., Csathó, A.I. \& Tóthmérész, B. 2018: Landscape and habitat and filters jointly drive richness and abundance of grassland specialist plants in terrestrial habitat islands. Landscape Ecology 33: 1117-1132. doi: https://doi. org/10.1007/s10980-018-0660-x

Deák, B., Tóthcs, Cs. A., Bede, Á., Apostolova, I., Bragina, T. M., Báthori, F., Bán, M. 2019: Eurasian Kurgan Database - a citizen science tool for conserving grasslands on historical sites. Hacquetia 18 (2): doi: 10.2478/hacq-2019-0007

Dembicz, I., Moysiyenko, I. I., Shaposhnikova, A., Vynokurov, D., Kozub, L. \& Sudnik-Wójcikowska, B. 2016: Isolation and patch size drive specialist plant species density within steppe islands: A case study of kurgans in southern Ukraine. Biodiversity and Conservation 25(12): 2289-2307. doi: https://doi.org/10.1007/s10531-016-1077-y
Diamond, J.M., \& May, R.M. 1976: Island biogeography and the design of nature reserves. In May, R.M (ed.): Theoretical Ecology, Principles and Application. Blackwell Scientific Publications, Oxford. 163-186.

Ellenberg, H., Weber, E. H., Düll, R., Wirth, V., Werner, W. \& Paulißen, D. 1992: Zeigerwerte von Pflanzen in Mitteleuropa (Indicator values of plants in Central Europe), Scripta Geobotanica 18 Verlag Erich Goltze KG, Göttingen, 258. (in German)

Gallé, L., Győrffy, Gy., Hornung, E., Kocsis, A., Körmöczi, L., Szőnyi, G. \& Vajda, Z. 1992: Arthropod communities of ecological islands surrounded by agricultural fields. In Zombori, L., Peregovits, L., (eds.), Proc. 4th European Congress of Entomology and XIII Internationale Symposium für die Entomofaunistik Mitteleuropas, 1-6 September 1991, Gödöllö, Hungary pp. 286-290.

Godó, L., Tóthmérész, B., Valkó, O., Tóth, K., Radócz, S., Kiss, R., Kelemen, A., Török, P., Švamberková, E. \& Deák, B. 2018: Ecosystem engineering by foxes is mediated by isolation in grassland fragments. Ecology and Evolution 8(14): 7044-7054. doi: https://doi. org/10.1002/ece3.4224

Jones, M. 2007: The European Landscape Convention and the question of public participation. Landscape Research 32: 613-633. doi: https://doi.org/10.1080/01426390701552753

Joó, K. 2003: Kunhalomkutatások (A Csípő-halom vegetációja). [Researches on kurgans (The vegetation of Csípö-mound)]. Tájökológiai Lapok 1(1): 87-96. (in Hungarian)

Kitov, G. 1993: The Thracian tumuli. Thracia 10: 39-80.

Krausz, K. \& Pápai, J. 2004: Egyenesszárnyú rovarok izolátumdinamikai vizsgálata kunhalmokon (Studies on the Orthoptera isolation-dynamics on kurgans). In Tóth, A. (ed.): A kunhalmokról más szemmel. Kisújszállás-Debrecen, pp. 89-107. (in Hungarian)

Lisetskii, F., Goleusov, V.P., Moysiyenko, I.I. \& Sudnik-Wójcikowska, B. 2014: Microzonal distribution of soils and plants along the catenas of mound structures. Contemporary Problems in Ecology 7: 282-293. doi: https://doi.org/10.1134/S1995425514030111

Lisetskii, F., Sudnik-Wójcikowska, B. \& Moysiyenko, I. 2016: Flora differentiation among local ecotopes in the transzonal study of foreststeppe and steppe mounds. Biology Bulletin 43(2): 169-176. doi: https://doi.org/10.1134/S1062359016010106

Molnár, M., Joó, K., Barczi, A., Szántó, Zs., Futó, I., Palcsu, L. \& Rinyu, L. 2004: Dating of total soil organic matter used in kurgan studies. Radiocarbon 46 (2): 413-419.

Molnár, M. \& Svingor, É. 2011: An interpretation of the soil 14C results of the Hajdúnánás-Tedej-Lyukas-halom kurgan. Kurgan Studies: An environmental and archaeological multiproxy study of burial mounds in the Eurasian steppe zone. BAR International Series 2238(11): 255-258.

Molnár V., A., Löki, V., Máté, A., Molnár, A., Takács, A., Nagy, T., Lovas-Kiss, Á., Lukács, B.A., Sramkó, G. \& Tökölyi, J. 2017 : The occurrence of Spiraea crenata and other rare steppe plants in Pannonian graveyards. Biologia 72: 500-509. https://doi.org/10.1515/ biolog-2017-0060

Molnár V., A., Mészáros, A., Csathó, A.I., Balogh, G., Takács, A., Löki, V., Lovas-Kiss, Á., Tökölyi, J., Somlyay, L. \& Bauer, N. 2018: Distribution and seed production of the rare, dry grassland specialist Sternbergia colchiciflora (Amaryllidaceae) in Pannonian cemeteries. Tuexenia 38: 371-384. doi: https://doi.org/10.14471/2018.38.015 
Mozolevsky, B.N. \& Polin, C.V. 2005: Kurgany skifskogo Gerossa IVB (Babina vodjana i cobolena mogili) [Kurgans of Scythian Gerros of 4th B.C. (Babina, Vodjana and Soboleva mogily)]. Stilos Publishing, Kiev.

Ponomareva, V. V. \& Plotnikova, T. A. 1980: Gumus i Pochvoobrazovanie (Humus and Pedogenesis), Nauka, Leningrad. 65-74.

Selmeczi, L. 1971: Angaben und Gesichtspunkte zur archäologischen Forschung nach den Kumanen im Komitat Szolnok. Móra Ferenc Múzeum Évkönyve 2. pp. 187-197.

Simon, T. 1992: A magyarországi edényes flóra határozója [Guide of the vascular flora in Hungary]. Tankönyvkiadó, Budapest. 892 pp. (in Hungarian)

Sudnik-Wójcikowksa, B., Moysiyenko, I.I. \& Zachwatowicz, M. 2011: The value and need for protection of kurgan flora in the anthropogenic landscape of steppe zone in Ukraine. Plant Biosystems 145: 638-653. doi: https://doi.org/10.1080/11263504.2011.601335

Szilágyi, G., Náfrádi, K. \& Sümegi, P. 2019: A preliminary chronological study to understand the construction phases of a Late Copper-Early Bronze Age kurgan (kunhalom). Central European Geology 62: 1-29. https:// doi.org/10.1556/24.61.2018.11

Tóth, Cs. 2006: Results of the national mound cadastering from the aspect of geological conservation. Acta Debrecina Geology, Geomorphology, Physical Geography Series Debrecen 1: 129-135.

Tóth, Cs. \& Tóth, A. 2011: The complex condition assessment survey of kurgans in Hungary. In Á. Pethő \& A. Barczi (eds.), Kurgan Studies: An environmental and archaeological multiproxy study of burial mounds in the Eurasian steppe zone. BAR International Series 2238. 11: 9-17.

Tóth, Cs., Pethe, M. \& Hatházi, Á. 2014: The application of earth science-based analyses on a twin-kurgan in Northern Hungary. Carpathian Journal of Earth and Environmental Sciences 9 (1): 11-20.

Valkó, O., Tóth, K., Kelemen, A., Miglécz, T., Radócz, S., Sonkoly, J., Tóthmérész, B., Török, P. \& Deák, B. 2018: Cultural heritage and biodiversity conservation - Plant introduction and practical restoration on ancient burial mounds. Nature Conservation 24: 65-80. doi: https://doi.org/10.3897/natureconservation.24.20019

Zólyomi, B. \& Fekete, G. 1994: The Pannonian loess steppe: differentiation in space and time. Abstracta Botanica 18 (1): 29-41.

\section{Appendix}

\section{Appendix 1. Animal species recorded in this study}

Chondrula tridens (O.F. Müller, 1774): This snail frequently appears on the southern side of the mounds. It prefers arid, warm habitats with a higher carbonate content. Occurs in Central, Eastern and Southern Europe.

Helicella obvia (Menke, 1828): A snail that can often be found on the soil surface and on the dry weeds of the total area of the mounds. It prefers a warm climate, relatively xerophyte. Occurs in Southern Europe.

Coptosoma scutellatum (Geoffroy, 1785): A hemipteran often found in arid places, most frequently on the plant species Ononis vulgaris. During the current research it could not be detected in the most arid habitat (eastern mound, southern side); however, it was frequent on the southern side of the mounds.

Cydnus aterrimus (Forster, 1771): A ground-dwelling hemipteran, frequently found on Euphorbiaceae. We detected it in on each of the four investigated areas of the mounds.

Sciocoris cursitans (Fabricius, 1794): Only one specimen occurred in the bottom section of the southern aspect of the western mound.

Cicindela germanica (Linnaeus, 1758): Six individuals, recorded on the northern side of the eastern mound. Occurs in Central and Southwestern Europe.

Carabus cancellatus (Illiger, 1798): Twenty-eight individuals, recorded in the open habitat with higher vegetation of the northern side of the eastern mound. Protected in Hungary.

Carabus violaceus (Linnaeus, 1758): It mostly preferred the open habitats rich in humus in the more humid northern areas. Protected in Hungary

Trechus quadristriatus (Schrank, 1781): It did not occur in the most arid habitats; we found it at vegetated, shaded locations.

Harpalus rufipes (De Geer, 1774): It preferred the highly vegetated northern side, rich in humus. The animal frequently occurred in agricultural areas as well. The adult is omnivorous, mainly eating insect larva and plant seeds.

Harpalus griseus (Panzer, 1797): It lives on the southern side of the western mound, in open and arid habitats with lower vegetation. Quite a widespread species in Hungary and one of the most frequent species of Carabidae in agricultural areas, as well.

Stomis pumicatus (Panzer, 1796): It occurred on soils rich in humus on the northern side of the western mound with a more balanced water supply. A widespread, but not frequent, species.

Pterostichus niger (Schaller, 1783): A eurytopic species that can be found at forest associations. In this case, we found it in $30-40 \mathrm{~cm}$ high vegetation on the northern side of the western mound.

Agonum dorsale (Pontoppidan, 1763): It occurs in open habitats with high vegetation but is also frequent in agricultural areas.

Panagaeus bipustulatus (Fabricius, 1775): a xerophyte species that lives in arid and sunny places. We were unable to find it on the southern aspect sides but it occurred on the northern side of the western mound inside $40 \mathrm{~cm}$ high vegetation.

Margarinotus ventralis (Marseul, 1854): It came up from the denser vegetation of the eastern mound. A frequent species in Hungary.

Nicrophorus fossor (Erichson, 1837): A specialized necrophagous burying beetle. Widespread in Hungary. 
Silpha obscura (Linnaeus, 1758): Its nutrition is based on rotten material, plant material or carrion; or it can be also a predator. It occurred in dense vegetation on the northern side of the western mound.

Dermestes laniarius (Illiger, 1801): Sixteen individuals, recorded in a habitat with dense vegetation.

Phradonoma villosulum (Duftschmid, 1825): Twenty individuals, recorded on the southern side of the western mound.

Hippodamia variegata (Goeze, 1777): Fourty-five individuals, recorded on an open, arid side with a southern aspect (western mound).

Coccinella septempunctata (Linneaeus, 1758): It is quite frequent in various terrestrial habitats in Hungary.

Propylea quatuordecimpunctata (Linnaeus, 1758): Mainly feeds on plant lice. Frequently occurs in Hungary.

Blaps lethifera (Marsham, 1802): Flightless ground-dwelling species that feeds on rotting plant parts. It occurred on the northern side of the eastern mound.

Opatrum sabulosum (Linnaeus, 1761): It is phytopphagous and it occurred in sparse vegetation on the southern aspect arid sides. Frequently occurs in Hungary. Rare in Italy, it has a small distribution on the southern slopes of the Alps where it is considered a steppe species.

Onthophagus ovatus (Linnaeus, 1767): They occurred on the northern side of the mounds with denser vegetation.

Rhizotrogus aestivus (Olivier, 1789): It occurred on the arid southern aspect side (eastern mound). Frequently occurs in Hungary.

Dorcus parallelipipedus (Linnaeus, 1758): It occurs in rotting wooden material. We found a specimen that flew to the northern side of the eastern mound. Protected in Hungary.

Dorcadion scopolii (Herbst, 1784): Frequently occurs in arid warmer grasslands and mainly in plain regions.

Cryptocephalus bipunctatus (Linnaeus, 1758): It lives on various broadleaf trees and shrubs. Quite frequent in Hungary.

Chrysomela limbata (Fabricius, 1775): Feeds on Plantago species. It occurs in plains and hilly areas in Hungary.

Galeruca tanaceti (Linnaeus, 1758): Frequently occurs in open grassy areas, often in quite arid grasslands (i.e. saline grasslands). Its food plants are: Achillea spp., Chrysanthemum spp., Taraxacum spp., Cirsium spp., Stellaria spp.

Cassida vibex (Linnaeus, 1767): Its food plants are: Cirsium arvense, C. palustre, Chrysanthemum vulgare. Common in Hungary.

Otiorhynchus orbicularis (Herbst, 1795): Occurs all over Central Europe, feeding on plant roots. It occurred on the northern sides with denser vegetation.

Otiorhynchus ovatus (Linnaeus, 1758): Feeds on Fragaria spp., Potentilla spp., Rumex spp. Frequently occurs in Hungary.

Baris lepidii (Germar, 1824): Frequently occurs in Hungary. Its food plants are: Rorippa spp., Lepidium spp.

Appendix 2. List of species collected by pitfall traps in the southern and northern exposed habitats of the Zsolca mounds.

\begin{tabular}{|c|c|c|c|c|c|}
\hline \multirow{2}{*}{ Name } & \multirow{2}{*}{ Family } & \multicolumn{2}{|c|}{ Southern slope } & \multicolumn{2}{|c|}{ Northern slope } \\
\hline & & $\begin{array}{c}\text { Mound } \\
\text { East }\end{array}$ & $\begin{array}{c}\text { Mound } \\
\text { West }\end{array}$ & $\begin{array}{c}\text { Mound } \\
\text { East }\end{array}$ & $\begin{array}{c}\text { Mound } \\
\text { West }\end{array}$ \\
\hline Chondrula tridens (Müller, 1774) & Enidae (Mollusca) & $\mathrm{x}$ & $\mathrm{x}$ & & \\
\hline Helicella obvia (Menke, 1828) & Helicidae (Mollusca & $\mathrm{x}$ & $\mathrm{x}$ & $\mathrm{x}$ & $\mathrm{x}$ \\
\hline Coptosoma scutellatum (Geoffroy, 1785) & Plataspidae (Heteroptera) & & $\mathrm{x}$ & $\mathrm{x}$ & $\mathrm{x}$ \\
\hline Cydnus aterrimus (Forster, 1771) & Cynidae (Heteroptera) & $\mathrm{x}$ & $\mathrm{x}$ & $\mathrm{x}$ & $\mathrm{x}$ \\
\hline Sciocoris cursitans (Fabricius, 1794) & Pentatomidae (Heteroptera) & & $\mathrm{x}$ & & \\
\hline Cicindela germanica (Linnaeus, 1758) & Cicindelidae (Coleoptera) & & & $\mathrm{x}$ & \\
\hline Carabus cancellatus (Illiger, 1798) & Carabidae (Coleoptera) & & & $\mathrm{x}$ & \\
\hline Carabus violaceus (Linnaeus, 1758) & Carabidae (Coleoptera) & $\mathrm{x}$ & & $\mathrm{x}$ & $\mathrm{x}$ \\
\hline Trechus quadristriatus (Schrank, 1781) & Carabidae (Coleoptera) & & & & $\mathrm{x}$ \\
\hline Harpalus rufipes (De Geer, 1774) & Carabidae (Coleoptera) & & & $\mathrm{x}$ & $\mathrm{x}$ \\
\hline Harpalus griseus (Panzer, 1797) & Carabidae (Coleoptera) & & $\mathrm{x}$ & & \\
\hline Stomis pumicatus (Panzer, 1796) & Carabidae (Coleoptera) & & & & $\mathrm{x}$ \\
\hline Pterostichus niger (Schaller, 1783) & Carabidae (Coleoptera) & & & $\mathrm{x}$ & \\
\hline Agonum dorsale (Pontoppidan, 1763) & Carabidae (Coleoptera) & & & & $\mathrm{x}$ \\
\hline Panagaeus bipustulatus (Fabricius, 1775) & Carabidae (Coleoptera) & & & & $\mathrm{x}$ \\
\hline
\end{tabular}




\begin{tabular}{|c|c|c|c|c|c|}
\hline \multirow{2}{*}{ Name } & \multirow{2}{*}{ Family } & \multicolumn{2}{|c|}{ Southern slope } & \multicolumn{2}{|c|}{ Northern slope } \\
\hline & & $\begin{array}{l}\text { Mound } \\
\text { East }\end{array}$ & $\begin{array}{l}\text { Mound } \\
\text { West }\end{array}$ & $\begin{array}{c}\text { Mound } \\
\text { East }\end{array}$ & $\begin{array}{l}\text { Mound } \\
\text { West }\end{array}$ \\
\hline Margarinotus ventralis (Marseul, 1854) & Histeridae (Coleoptera) & & & $\mathrm{x}$ & \\
\hline Nicrophorus fossor (Erichson, 1837) & Silphidae (Coleoptera) & & & $\mathrm{x}$ & \\
\hline Silpha obscura (Linnaeus, 1758) & Silphidae (Coleoptera) & & & & $\mathrm{x}$ \\
\hline Dermestes laniarius (Illiger, 1801) & Dermestidae (Coleptera) & & & & $\mathrm{x}$ \\
\hline Phradonoma villosulum (Duftschmid, 1825) & Dermestidae (Coleptera) & & $\mathrm{x}$ & & \\
\hline Hippodamia variegata (Goeze, 1777) & Coccinellidae (Coleoptera) & & $\mathrm{x}$ & & \\
\hline Coccinella septempunctata (Linneaeus, 1758) & Coccinellidae (Coleoptera) & $\mathrm{x}$ & $\mathrm{x}$ & $\mathrm{x}$ & \\
\hline Propylea quauordecempunctata (Linneaeus, 1758) & Coccinellidae (Coleoptera) & & & & $\mathrm{x}$ \\
\hline Blaps lethifera (Marsham, 1802) & Tenebrionidae (Coleoptera) & & & $\mathrm{x}$ & \\
\hline Opatrum sabulosum (Linnaeus, 1761) & Tenebrionidae (Coleoptera) & $\mathrm{x}$ & $\mathrm{x}$ & & \\
\hline Ontophagus ovatus (Linnaeus, 1767) & Scarabaeidae (Coleoptera) & & & $\mathrm{x}$ & $\mathrm{x}$ \\
\hline Rhizotrogus aestivus (Olivier, 1789) & Scarabaeidae (Coleoptera) & $\mathrm{x}$ & & & \\
\hline Dorcus parallelopipedus (Linnaeus, 1758) & Lucanidae (Coleoptera) & & & $\mathrm{x}$ & \\
\hline Dorcadion scopolii (Herbst, 1784) & Cerambycidae (Coleoptera) & & $\mathrm{x}$ & $\mathrm{x}$ & \\
\hline Cryptocephalus bipunctatus (Linnaeus, 1758) & Chrysomelidae (Coleoptera) & & & & $\mathrm{x}$ \\
\hline Chrysomela limbata (Fabricius, 1775) & Chrysomelidae (Coleoptera) & & & & $\mathrm{x}$ \\
\hline Galeruca tanaceti (Linnaeus, 1758 & Chrysomelidae (Coleoptera) & $\mathrm{x}$ & & & \\
\hline Cassida vibex (Linnaeus, 1767) & Chrysomelidae (Coleoptera) & & & & $\mathrm{x}$ \\
\hline Otiorhynchus orbicularis (Herbst, 1795) & Curculionidae (Coleoptera) & & & $\mathrm{x}$ & $\mathrm{x}$ \\
\hline Otiorhynchus ovatus (Linnaeus, 1758) & Curculionidae (Coleoptera) & $\mathrm{x}$ & $\mathrm{x}$ & & $\mathrm{x}$ \\
\hline Baris lepidii (Germar, 1824) & Curculionidae (Coleoptera) & & $\mathrm{x}$ & & \\
\hline Total species & & 9 & 13 & 16 & 18 \\
\hline
\end{tabular}

$x$ : Occurs in the habitat 